\title{
Paleogeographic Evolution of the Eastern Edge of the Douala Basin from Early Cenomanian to Turonian
}

\author{
Njike N.P. Ricard ${ }^{1}$, Mfayakouo C. Bachirou ${ }^{*}, 2$ and Bitom Dieudonné ${ }^{3}$ \\ ${ }^{1}$ Department of Earth Science, Faculty of Science, University of Dschang, P.O. Box 69 Dschang, Cameroon \\ ${ }^{2}$ Department of Earth Sciences, Faculty of Science, University of Maroua, P.O. Box 46 Maroua, Cameroon; University \\ of Yaounde I, P.O. Box 812 Yaounde, Cameroon \\ ${ }^{3}$ Department of Earth Sciences, Faculty of Science, University of Ngaoundere, P.O. Box 454 Ngaoundere, Cameroon
}

\begin{abstract}
In order to trace the paleogeographic evolution of the eastern edge of the Douala basin from lower Cenomanian to Turonian, sedimentological and palynostratigraphic analyses have been carried out. The studied formations are about $80 \mathrm{~m}$ thick and are made up of continental detrital facies, which are coarse at the bottom and progressively become finer towards the top of the sequence. These rocks are overlain by marine deposits, composed of thin layers of black clay and bioclastic limestone. These formations were deposited during two sedimentation phases, namely, the continental deposit phase, which is composed of conglomerates infilling the basin, followed by the transgressive deposits associated with deepening of the basin environment. Sequence analysis of these different facies, indicates that the turbidites are composed of small sequences that constitute a transgressive megastructure. This succession was deposited during a megatransgressive phase that continued until the final stage of the basin infilling. According to palynologic data, strata were deposits from the early Cenomanian at the bottom to the Turonian towards the top. The depositional environment changed over time, passing from (1) a narrow and steep-sided tectonic basin, during the early to middle Cenomanian, followed by (2) a lacustrine to palustrine basin with marine incursions, as a result of the E-W distensive movements between the South American and Northwest African blocks in the middle and late Cenomanian, and (3) to a confined and shallow sea during the Turonian. The climate remained warm and became progressively humid towards the end of the Cretaceous. The nature of these environments is related to the dynamics of the opening of the South Atlantic Ocean.
\end{abstract}

Keywords: Cenomanian, depositional environment, douala basin, paleogeography, palynostratigraphy, transgressive megasequence, turonian.

\section{INTRODUCTION}

The Cameroonian coastal basin outcrops in three separate units, namely, the Kribi/Campo basin, Douala basin and Rio del Rey or Bamusso basin. These basins are part of the West African margin formed during the gradual widening of the South Atlantic by the South-North continental tear [1]. The Douala basin (Fig. 1) is the subject of this study and is also the subject of numerous studies describing the tectonosedimentary evolution most of which are related to the Cretaceous rifting and formation of a continental margin [24]. Therefore, the Cretaceous is a period during which structural, stratigraphic and geodynamic history have been extensively studied for several decades ([5-11] etc.) and may now seem to be well known. The identification and mapping of Cretaceous deposits throughout the Douala basin have been established cumulatively from both outcrops and boreholes. Multidisciplinary studies carried out on the entire

*Address correspondence to this author at the Department of Earth Sciences, Faculty of Science, University of Maroua, P.O. Box 46 Maroua, Cameroon; Tel: (237) 75054572 ;

E-mails: bmfayakouo@gmail.com,mfayakouo@yahoo.fr
West African margin give an overall view of the paleogeography of this margin during the Cretaceous [2, 12]. However, this picture remains generalized and does not reveal the specificity of each basin as the South Atlantic progressively widened. Regarding the Douala basin, a few attempts have been made to reconstitute its paleogeography on the basis of palynological studies conducted by Boltenhagen and Salard-Cheboldaeff [13] and Njike Ngaha [8], respectively on drilling and outcrop samples. Despite these efforts, the paleogeographic evolution of this basin during the Cretaceous remains unknown especially for the Cenomanian-Turonian interval.

The purpose of this article is to trace the paleogeographic evolution of the Douala basin during the CenomanianTuronian interval. To achieve this, sedimentological and palynostratigraphic analyzes were performed on deposits exposed at the eastern edge of the basin to: (1) identify the different facies found and the conditions under which they were deposited, (2) determine the age of the various palynomorphs identified in these deposits, and (3) identify the different depositional environments and their dynamics in space and time. 


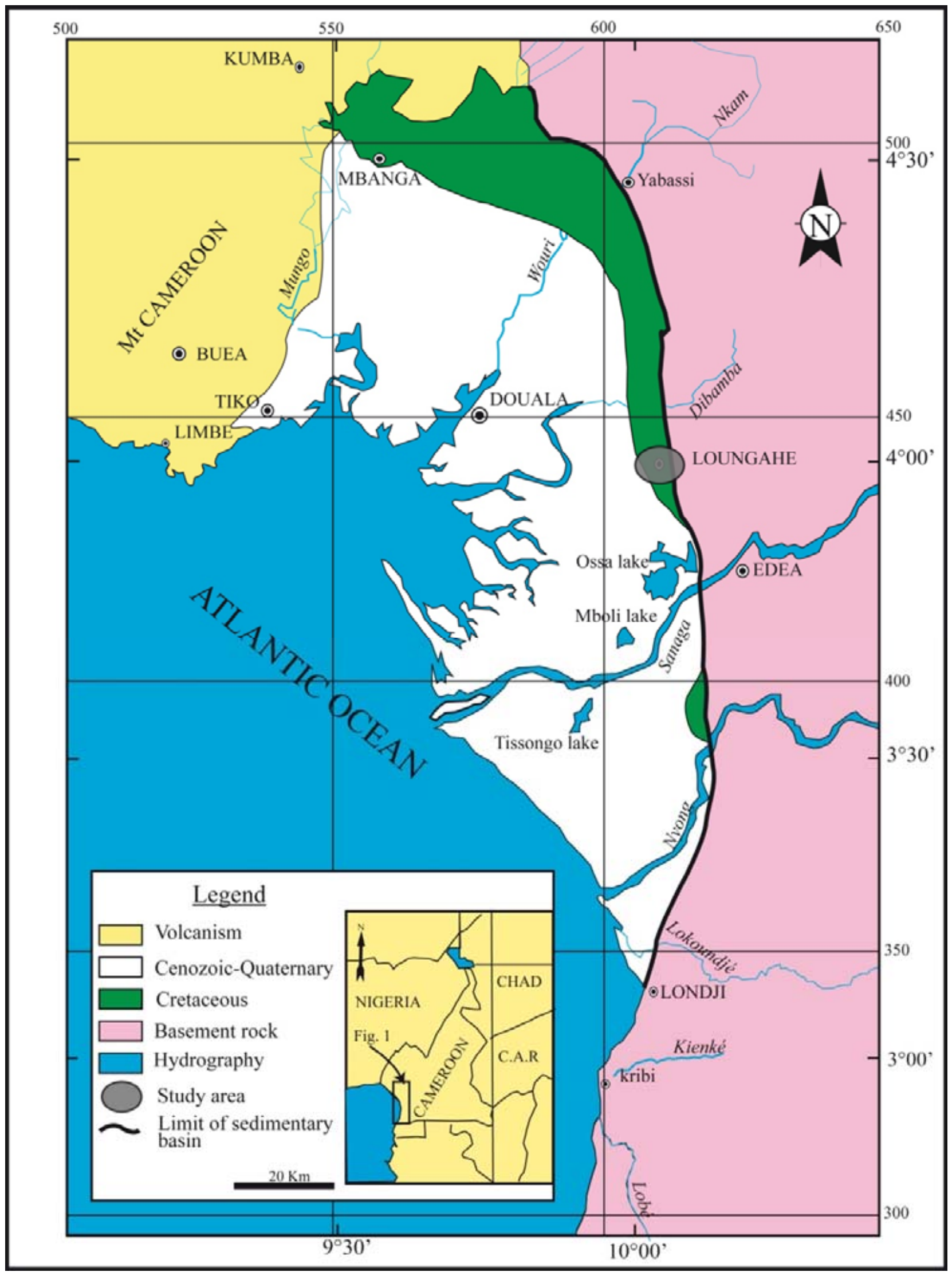

Fig. (1). Location of Douala basin in the Gulf of Guinea (after Njike Ngaha, 2005). 


\section{GEOLOGY}

The geology of the basin is characterized by igneous and metamorphic rocks constituting a Precambrian basement. Plutonic activity is shown by the presence of anatexites, granites and a charnockitic complex. Metamorphism is displayed by the presence of gneiss associated with migmatites in the eastern part of the basin, amphibolites and micaceous quartzite sometimes with tourmaline in the northern and north-eastern fringes of the basin. This bedrock is affected by dextral shearing faults that are likely to be an extension of the transforming faults of Fernando Po and Ascension fracture zones [3, 4, 14]. The Douala basin has a history that is similar to all the basins of the West African margin $[7,14,15,16]$. These basins were formed by a rift phase in the early Cretaceous followed by an east-west drift phase during the widening of the South Atlantic in midCretaceous times. The geodynamic context of their tectonostratigraphic development has been summarized $[11,17]$ in three phases: the syn-rift phase (Apto-Albian), the transition phase (Albian-Cenomanian) and the expansion and marginal oceanic accretion phase (Cenomanian to present).

- The syn-rift phase (Apto-Albian) corresponds with the formation of the graben-type rift materializing the rupture between the African and South American plates. Crustal distension generated tilted block tectonics and coarse detrital infilling sediments from the edges of the rift that were deposited in depressions formed during this rifting period.

- The transition phase (Albian-Cenomanian) corresponds with the heightening of the fracture between the two plates. It is marked by lagoonallacustrine (silty clay) type deposits, by potassium and sodium salts identified in the conjugate margin basins of Brazil and Angola to Gabon [15] and secondarily in the Kribi-Campo offshore sub-basin $[11,18]$. This saliniferous episode is practically absent in the Douala basin $[10,11]$.

- The expansion and marginal oceanic accretion phase stretches from the Cenomanian to present. This phase is characterized by deposits of siliciclastic and carbonate prograding sedimentary prisms followed by terrigenous detrital deposits. The architecture of these prograding prisms is regulated by relative changes in sea level interplaying with subsidence, eustacy and probably climate.

\section{MATERIALS AND METHODOLOGY}

The study site is located on the eastern edge of the Douala basin and covers the southern area of the locality of Loungahé and its surroundings (Fig. 2). The thick vegetation and lateritic cover make it difficult for sedimentary formations to be analyzed in outcrops. However, a general lithostratigraphic log was obtained from the study of the few outcrops identified in the area from road trenches and denuded banks of undergrowth streams (Fig. 3). Thus, almost 80 metres of sediments representing the lower deposits of the basin were observed, described and sampled. Use was also made of some core samples selected from the collections of the former South-East Mining Project during its survey in the study area between 1989 and 1990 before it closed. Description of various encountered lithofacies was done according to several criteria as principally: lithology, texture, nature of contacts between lithofacies and internal structures of each lithofacies.

For palynological analysis, carbonaceous clays, clayey sands and silty clays samples were collected from the top of these deposits. They contain palynomorphs that were used to determine relative age. Approximately $100 \mathrm{~g}$ of sediment per sample was subjected to a chemical pre-treatment consisting of a classic 12 hours attack with heated hydrochloric $(\mathrm{HCl})$ and hydrogen fluoride (HF) acids. After neutralization, the palynological residue was centrifuged in a zinc chloride $\left(\mathrm{ZnCl}_{2}\right)$ solution to separate organic material from mineral particles. The organic residue was then filtered and concentrated. Each sample was then oxidized with steaming nitric acid in order to remove all non-biological organic elements. The samples were mounted between slide and coverslip in Canada balsam for microscopic scrutiny. The slides were observed using a Leitz ORTHOPLAN microscope equipped with a Leica/Leitz photographic device and a micrometre objective. The semi-quantitative study was based on counting at least 200 grains of different palynomorphs in each sample.

\section{LITHOFACIES}

The lithofacies were described mindful of lithology, texture, internal structures and nature of the contact surfaces. Identification of each lithofacies was made easy by prior works [8, 19-22]. Each lithofacies was codified according to the nomenclature of Miall [20] and Potsma [22]. Five main facies and subfacies were identified at the eastern edge of the Douala basin namely the conglomeratic, sandstone, silty, clay, and carbonate facies.

\subsection{Conglomeratic Facies}

\subsubsection{Description}

This facies is found at the bottom of the studied series. It constitutes about one third of the studied sediments. It consists of coarse material (gravel and boulders), some of whose diameters ranged between $4 \mathrm{~cm}$ and $1.5 \mathrm{~m}$. These elements are gneissic, granitic and sometimes quartzitic and consolidated by medium sandy clay cement ("clastsupported"), with angular and subrounded elements. The nature of this cement gives them more or less reddish (ferruginous) colour. Its overall thickness is estimated at about $28 \mathrm{~m}$. These conglomerates ( $\mathrm{Gcm}, \mathrm{Gmg}$ ) are polygenic and polymictic, and are discordant at the base (Fig. 4a-c). They are sometimes associated with coarse to medium sandstone facies $(\mathrm{Sm})$ and are inclined at about $15^{\circ}$ to the west.

\subsubsection{Interpretation}

The Gcm facies, is likely to be the result of an abundant debris flow, accompanied by gravity sliding $[20,23]$ on the inclined edge of the widening rift. The sandy clay matrix indicates that the flowing mass remained highly concentrated and the elements remained consolidated during deposition 


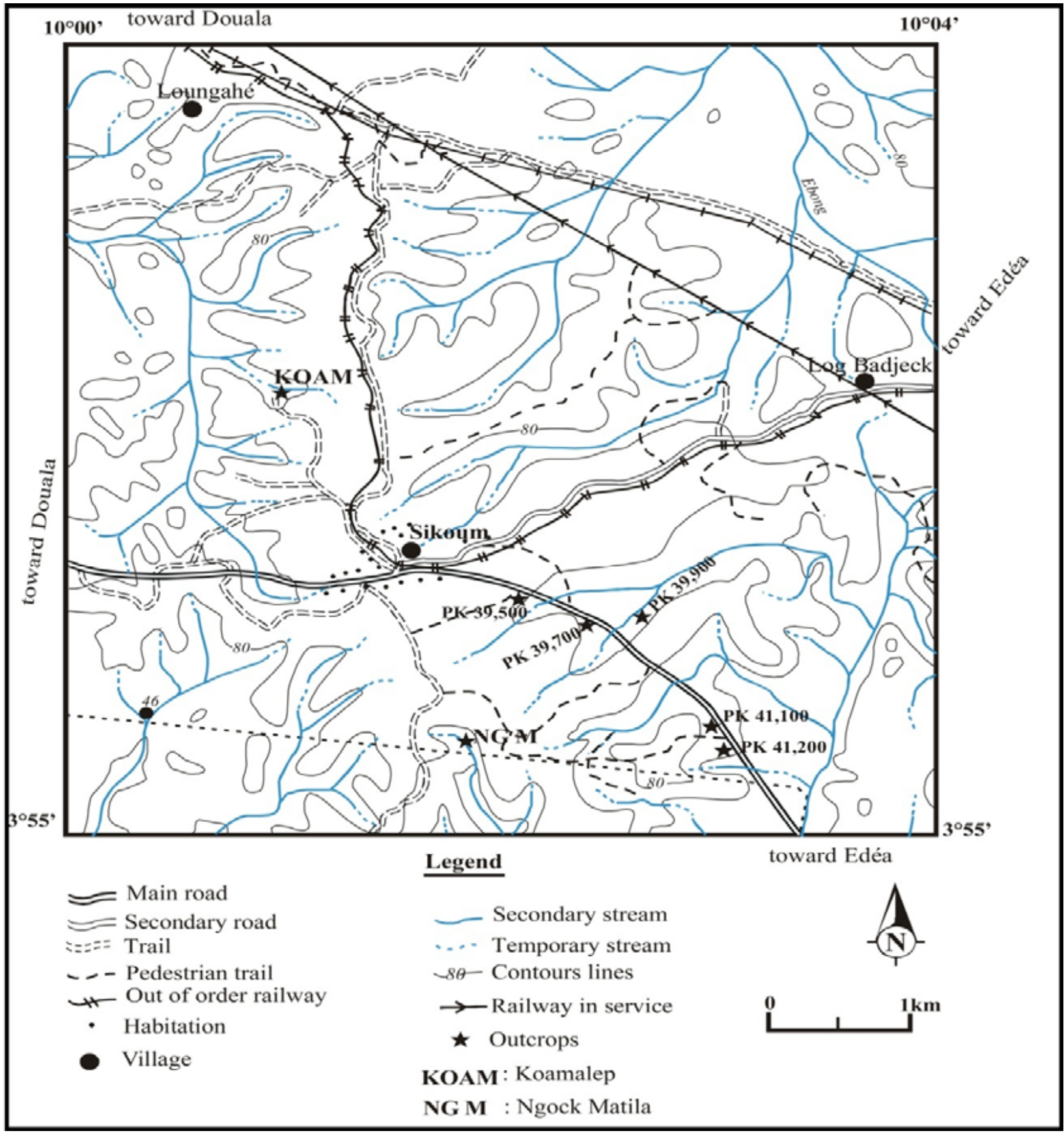

Fig. (2). Location of outcrops in the study area in the eastern edge of Douala basin.

[24]. Facies Gmg is a pseudoplastic grain flow deposit [25]. These conglomerates may have resulted from an alluvial fan accumulation in response to uplift and erosion of the rift edges [26]. These facies were affected by late uplift of the bedrock that adjusted the strata until the direction of dip was reversed and modified them to more than $50^{\circ}$ inclination to the east [10].

\subsection{Sandstone Facies}

\subsubsection{Description}

Sandstone facies are the main deposits found at the eastern edge of the basin. They consist of coarse to medium sandstone with a massive structure (Sm), medium to fine cross-bedded sandstone ( $\mathrm{St}$ ), fine sandstone with clay cement and silts in thin centimetre to decimetre layers alternating with grey to black clays of millimetre thicknesses, laminated, fossiliferous and rich in organic matter (Fig. 4d). This facies contains horizontal laminae in some places (Fig. 4f). These facies represent approximately $45 \%$ of the studied facies and generally have a fining-upward structure. Medium to coarse sandstone has a massive structure (facies Sm) with rounded to subangular mainly quartz elements. This facies has a ferruginous sandstone matrix that gives it a reddish colour and is sometimes associated with $\mathrm{Gcm}$ and $\mathrm{Gmg}$ facies. Medium to fine sandstone $(\mathrm{St})$ has a sandy clay matrix and 


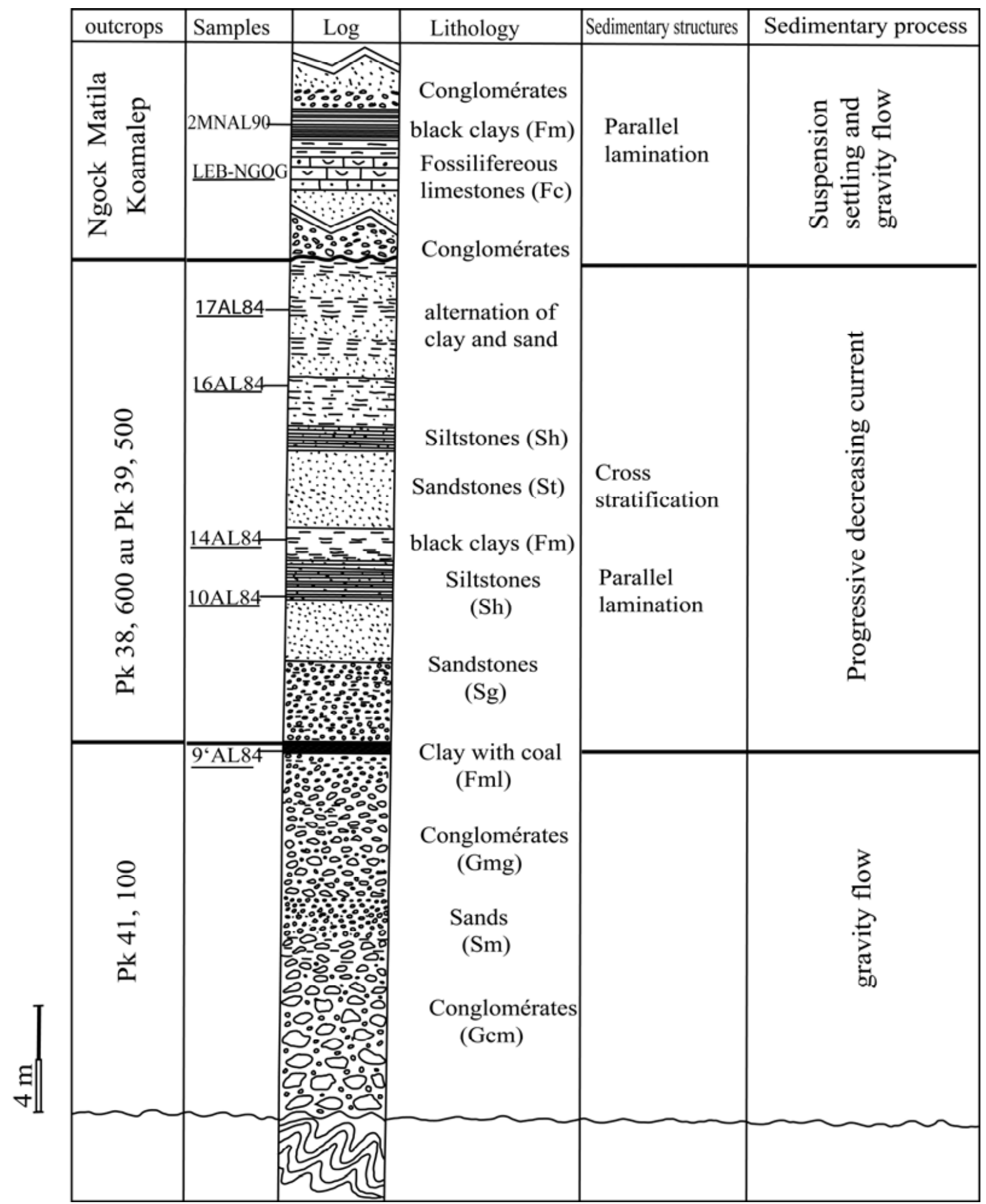

Fig. (3). Detail facies log of formations cropping out in the eastern edge of Douala basin and sample positions.

shows cross-bedding (Fig. 4e). They are most often associated with clay and silt facies alternating to the top. Fine sandstones are associated with silt facies and constituted the transition between the medium sandstone and silty-clay facies. They are consolidated with relatively horizontal layerings that are comparatively marked (Sh facies). They are less abundant than the coarse and medium sandstone. These sediments are fairly-well to well graded, poorly sorted regarding coarse grains and well sorted concerning fine grains. 

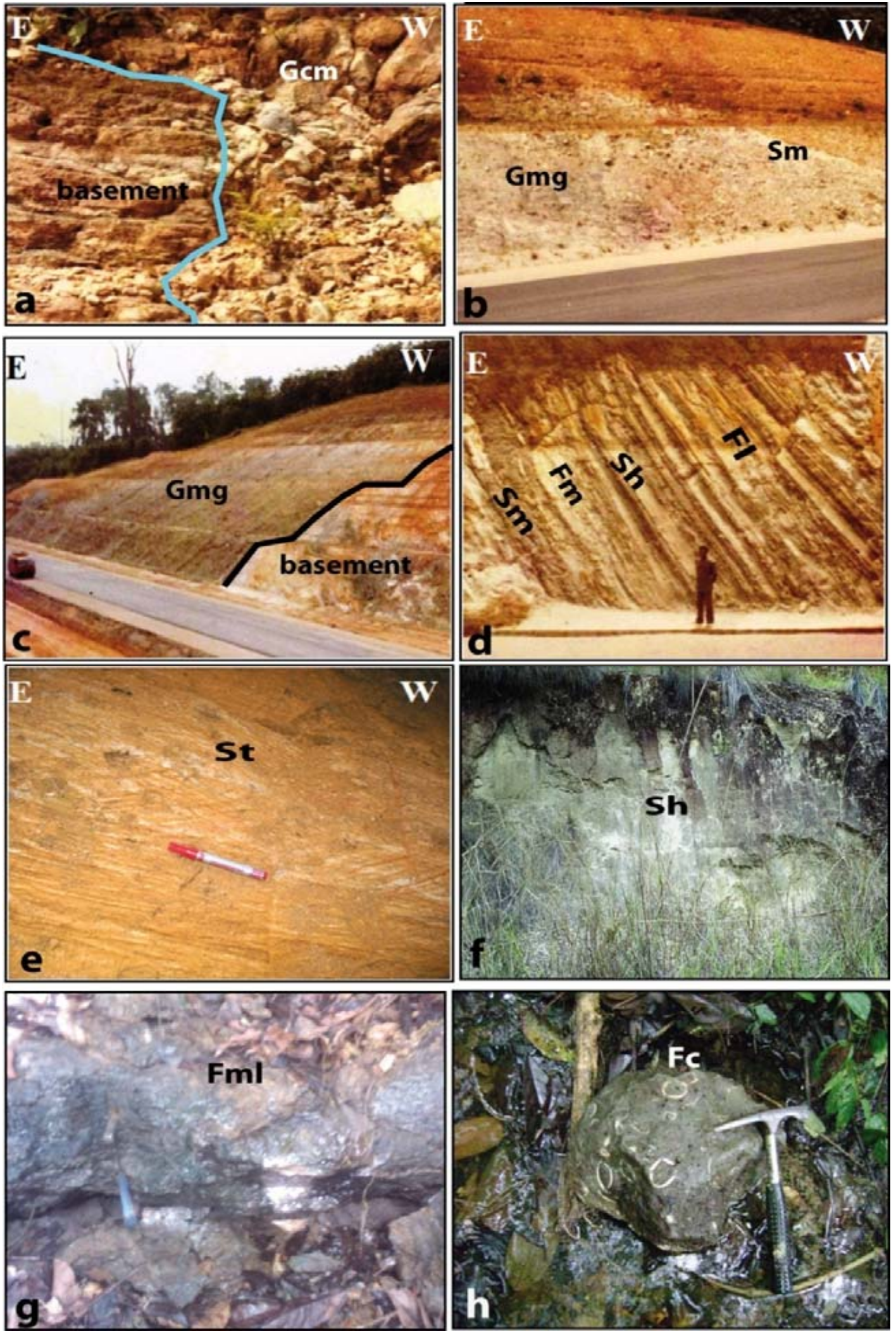

Fig. (4). Main facies encountered cropping out in the eastern edge of Douala basin. a) Gcm facies (conglomerate sandstones with clay matrix without sedimentary structures, rest on unconformity surface); b) Gmg facies (conglomerate with sandstone matrix "clast supported" associated to Sm facies); c) Gmg facies rest on unconformity surface, noted the beds inclination, with dip up to $50^{\circ}$; d) vertical succession of $\mathrm{Sm}, \mathrm{Fm}, \mathrm{Sh}$, and Fl facies, noted the beds inclination, with dip up to 50 to $70^{\circ}$; e) St facies (medium to fine sandstone with cross-bedding); f) Sh facies (fine to medium sandstone showing horizontal lamination); g) Fml facies (grey to black clays with some carbonaceous debris, rich in organic matter); h) Fc facies (very rich in animal debris limestones). 


\subsubsection{Interpretation}

Coarse sandstone with massive structure $(\mathrm{Sm})$ is interpreted as sandy deposits from a turbulent suspension of high concentration of mass flows or high density subaqueous turbidity currents [27]. Medium to fine cross-bedded sandstone (St) are likely to be deposits left by lateral accretion in a meandering channel $[28,29]$, the result of the migration of ripples or megaripples [20], or the result of numerous changes that occurred over time in the speed and direction of currents [30]. Fine sandstone with horizontal bedding is likely to be constructed by vertical accretion during periods of low flow regime [31, 32]. The positive sequences reported here suggest a gradual bottom to top decrease in deposition energy.

\subsection{Silty Facies}

\subsubsection{Description}

This facies is present at the top of studied series and represents approximately $5 \%$ of sandstone facies (facies F1). Their overall colour is grey, with some traces of reddening probably due to alteration (Fig. 4d). The strata have a thickness of not more than $1 \mathrm{~m}$ and sometimes present parallel laminations and bioturbation traces. They are associated with sandy facies with which they form rhythms of positive polarity.

\subsubsection{Interpretation}

The presence of parallel laminations in facies (F1) suggests that these are floodplain deposits dropped during periods of reduced discharge by vertical accretion or water torrents in shallow environment [30, 33, 34]. Traces of plant roots and bioturbation indicate an association with overflow or flood plain deposits.

\subsection{Clay Facies}

\subsubsection{Description}

These are shale (laminated), carbonaceous and sometimes pyritic, grey to black in colour, with some traces of bioturbation and are not very thick. Some facies are rich in organic matter and marine fossils (facies Fml). They are found at the top of conglomerates interbedded in sandstones, in combination with fossil limestone and regularly alternating with silts (Fig. $4 \mathbf{d}, \mathbf{g}$ ). They represent about $25 \%$ of the facies studied. They usually have a massive structure and some have fine parallel laminae (Fm, Fl and Fml).

\subsubsection{Interpretation}

Clay deposits are sediments formed by suspension settling in calm environments that can be flood plains, marshes and lakes. The presence of organic matter and marine fossils in some clay facies suggest a shallow marine environment relatively anoxic or closed, which favoured the preservation of organic matter. This could be a brackish environment that characterizes a pro-delta [35].

\subsection{Carbonate Facies}

\subsubsection{Description}

This is a grey to black limestone facies containing bivalve fragments (moulds and shells) (facies Fc). This facies represents about $5 \%$ of the studied facies. It is thin and associated with black shale facies (Fml). It has a compact and massive structure, and is very indurated (Fig. 4h). It is also characterized by the presence of scattered quartz pebbles, which appear subangular and are clear. The abundant fauna consists mainly of large, well-preserved, blunt and calcitic bivalve shells.

\subsubsection{Interpretation}

This facies was deposited in a shallow marine environment, very turbulent and was still undergoing continental influence, shown by the presence in this limestone of numerous subrounded to rounded quartz pebbles. Deposition of this facies can also be linked to good oxygenation of water and a warm climate. The period of oxygenation is attested by the presence of many fossil fragments [36]. This environment probably remained agitated because of the shallowness of the water.

\section{PALYNOSTRATIGRAPHY}

Thin palynomorph slides (14) were obtained. From these slides, 172 different palynomorph species were found. In the context of this work, 35 species including 9 marine (mostly Dinophyceae and 1 chitinous microforaminifera) and 26 continental (Pteridophytes and Spermaphyta) were used for dating the sediments studied. These are:

- For marine elements: Cribroperidium sp. cf. $C$. tensiftense, Substilisphaera sp. cf. S. pirnaensis, Florentinia sp., Spiniferites ramosus, Spiniferites ramosus subsp. ramosus, Substilisphaera pirnaensis, Exochosphaeridium bifidum, Palaeohystrichophora infusarioides (Dinophyceae) and Trochiliascia sp. cf. T. cuvillieri (Chitinous microforaminifera).

- $\quad$ For continental elements (spores and pollen grains): Deltö̈dospora sp. cf. D. germania, Densoisporites microrugulatus, Reticulatosporites jardinus, Acanthotriletes sp., Cicatricosisporites australensis, Cicatricosisporites subrotundus, Classopollis brasiliensis, Classopollis sp. cf. C. jardinei, Classopollis turosus, Inaperturopollonites sp. cf. I. limbatus, Inaperturopollenites Gigantus, Matonisporites phlebopteroides, Ephedripites sp., Inaperturopollinites magnus, Monocolpites sp. aff. Gemmanocolpites sp., Tricolpporopollenites sp. S. CI 141, Araucariacites australis, Cycadopites sp. cf. $M$. jardinei, Milfordia sp. cf. M. jardinei, Monocolpites sp., Ephedripites (Ephedripites) cf. E. regularis, Monosulcites sp. cf. M. ligneolatus, Triorites sp. 3, Graminidites sp. cf. G. gracilis n. sp., Tricolpites sp. cf. T. sagax, Tricolpopollenites sp. These palynomorphs helped to identify palynoplanctonic zones. 


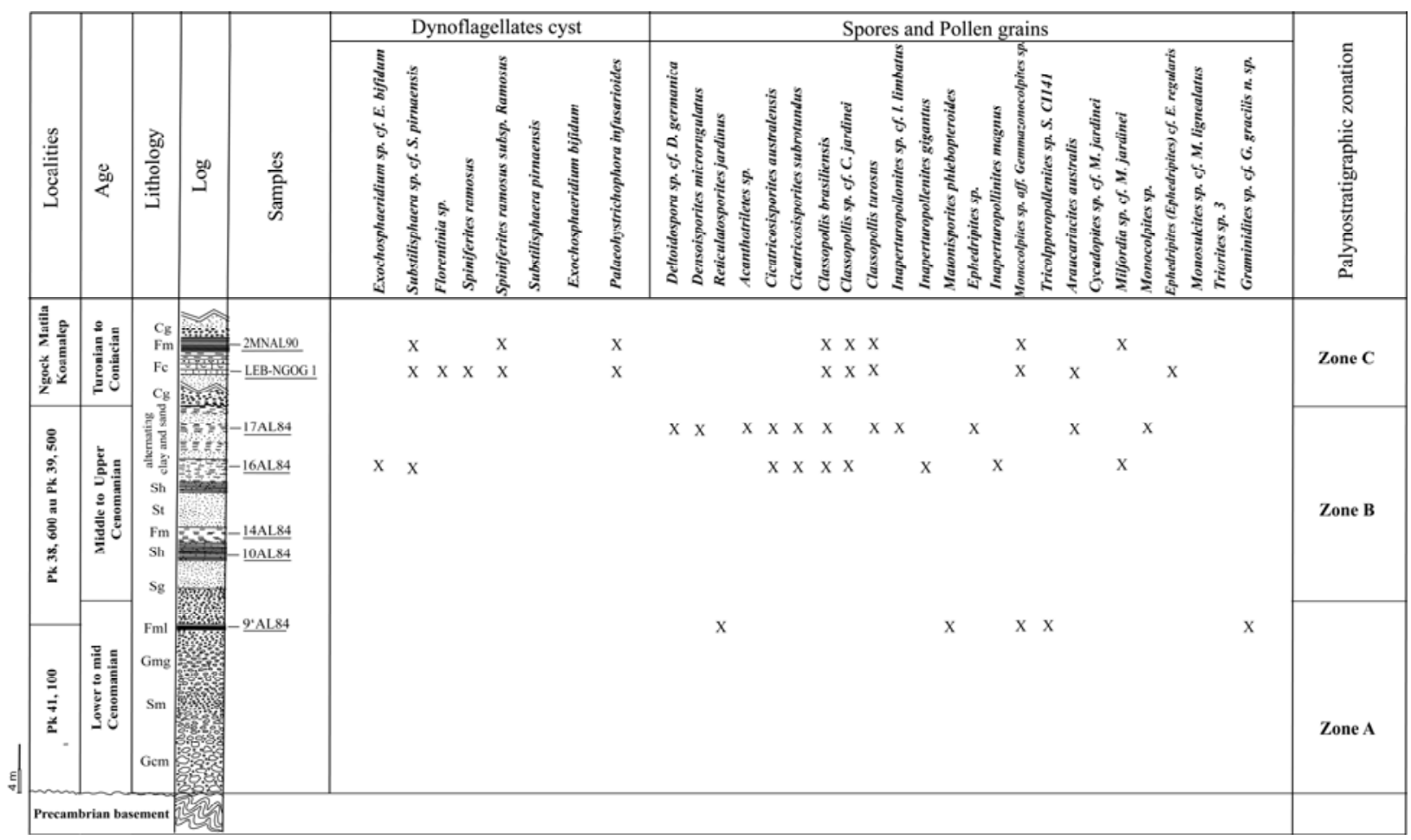

Fig. (5). Stratigraphic distribution of palynomorphs during late Cenomanian to Turonian from samples collected in the formations cropping out in the eastern edge of Douala basin.

The known periods of occurrence for the palynomorphs found in the sampled outcrops were compared with the age of the lithofacies established by reference collections, to make dating of exposed palynoplanctonic zones more reliable (Fig. 5).

\subsection{Palynostratigraphic Zones}

\subsubsection{Zone A}

This zone corresponds to that of polygenic conglomerates with sandy clay at the bottom of the basin. $70-80 \%$ of palynomorphs found in carbonaceous clays from the top of these deposits suggest a middle Cretaceous age, specifically Albian-Cenomanian [8]. Moreover, the dominant spore (70, $37 \%$ ), Reticulatasporites jardinus is known to belong to the Early to middle Cretaceous age in Peru, Brazil, Senegal, Guinea Bissau, Ghana, Nigeria, Gabon, Congo, Angola, Côte d'Ivoire, Morocco and Algeria [37]. It is also found in the Albian-Cenomanian in the coastal basin of Gabon. Accordingly, we suggest this zone to be early to middle Cenomanian (Fig. 6).

\subsubsection{Zone B}

This zone consists of coarser terrigenous continental facies at the bottom and fine-grained at the top with several clayey and silty clay layer often containing plant or carbonaceous debris. It finishes with a thin layer of grey limestone and grey to black clay, with a very fossiliferous marl trend. Several authors $([5-7,38,39]$ attributed the continental deposits at the bottom of this zone to a Cenomanian age, based on the fossil content, and the clay an carbonate facies at the top to an early Turonian age. Countless undetermined shells and especially bivalves of the Cardium, Inoceramus, Exogyra and Venericardia genus were identified in the field.

Palynomorphs constituting this zone (Figs. 7-10) helped to subdivide it into three palynoplanctonic sub-zones whose ages of occurrence extend from middle to Late Cretaceous [10]. Mindful of the well known exact dating of limestones and clays (early Turonian), the underlying continental deposits are likely to be of the middle to late Cenomanian. This zone B is subdivided as follows:

Sub-zone B1 (Figs. 7, 8) is likely to be of an age that is close to the end of the middle Cenomanian because of the predominance of Inaperturopollenites giganteus (middle Cretaceous in Gabon [37] and Classopollis sp. cf. C. jardinei (Albian-Cenomanian).

Sub-zone B2 (Fig. 9) is likely to be of the late Cenomanian because of the presence of palynomorphs at the bottom of the late Cretaceous such as Araucariacites australis, Acanthotriletes sp. aff. A. rarispinosus, Cyathidites minor, Ephedripites sp., Triporoletes cf. T. tympanoideus, Trochiliascia sp. cf. T. cuvillieri.

Sub-zone B3 (Fig. 10) is characterized by large numbers of Classopollis brasiliensis, Classopollis sp. jardinus, Monocolpites sp. aff. Gemmazonocolpites sp. etc. that are mid-Cretaceous palynomorphs in association with mid- 


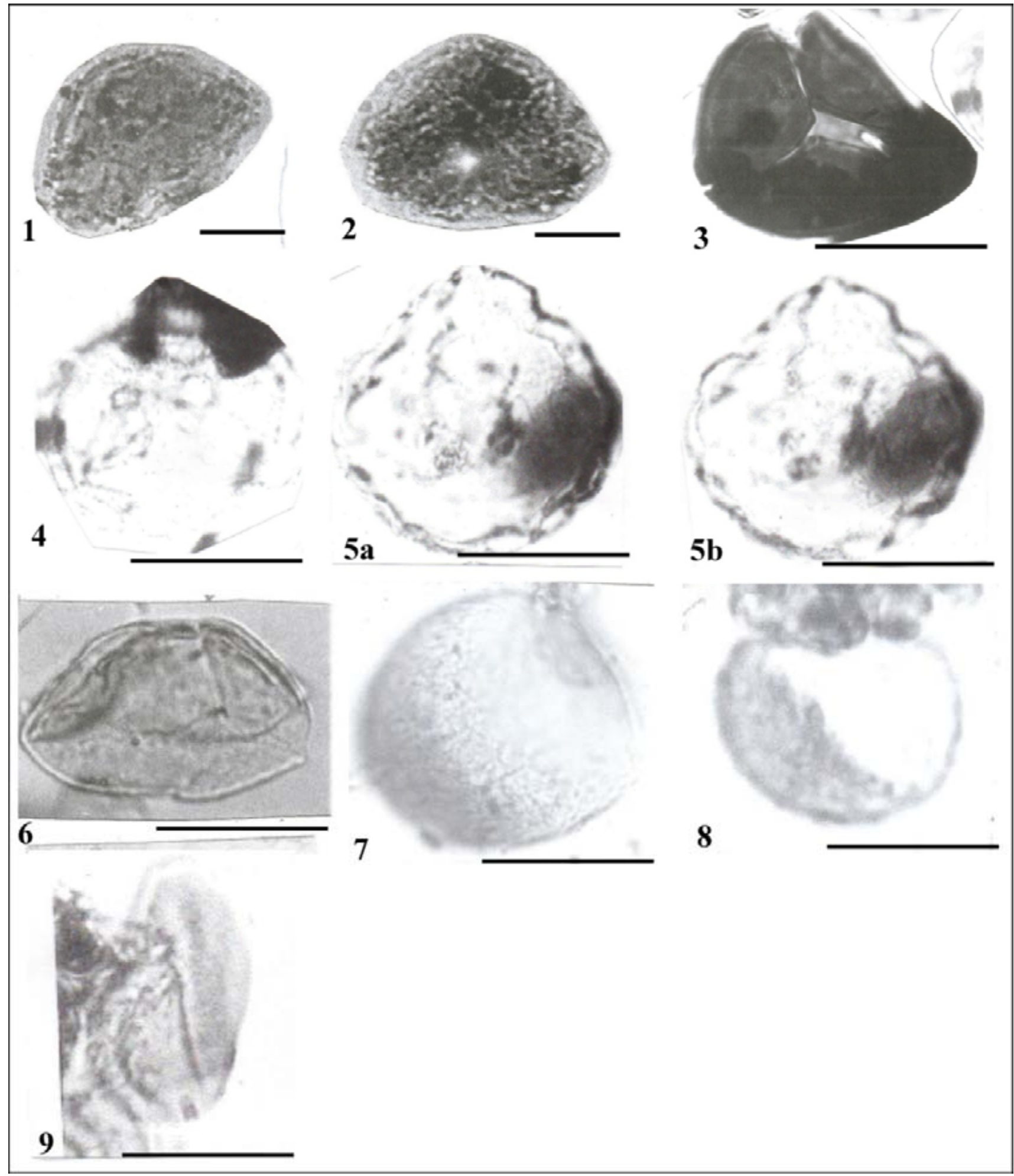

Scale bar $=\mathbf{3 0} \boldsymbol{\mu}$

Fig. (6). Zone A legend: 1 and $\mathbf{2}=$ Reticulatasporites jardinus, Brenner (1968); 3 = Matonisporites phlebopteroides, Couper (1958); 4, 5a and $\mathbf{5 b}=$ Leptolepidites bullatus, Van hoeken-Klinkenberg (1964); Srivastava S K (1972); 6 = Laevigatosporites ovatus; $7=$ Graminidites sp. aff. G. crassipunctatus sp., Krutzsch (1970); 8 and $9=$ Graminidites sp. cf. G. gracilis n. sp., Krutzsch (1970). 


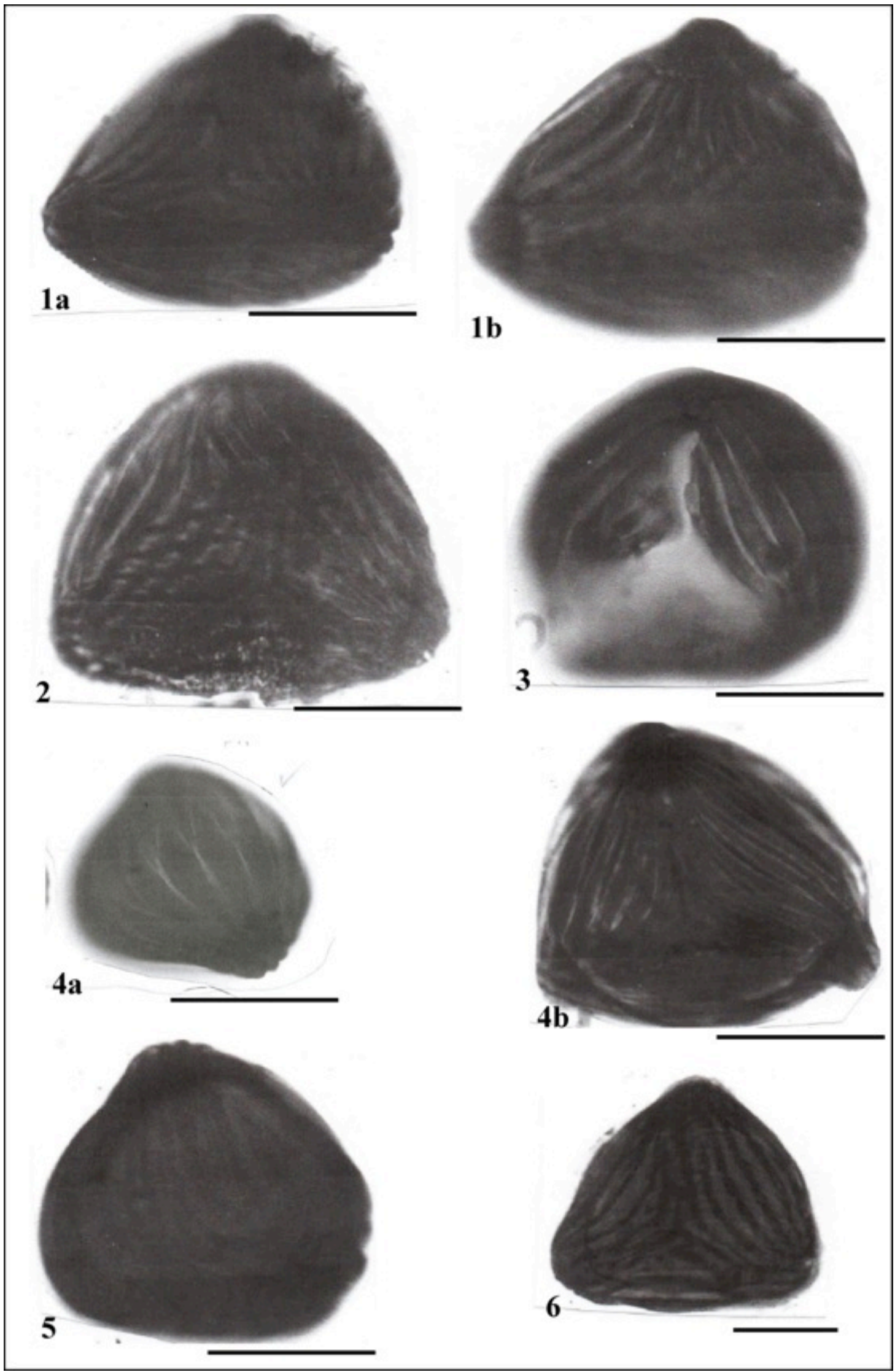

Scale bar $=\mathbf{3 0} \boldsymbol{\mu}$

Fig. (7). Zone B1 legend: 1a, 1b, 2 and $\mathbf{3}$ = Cicatricosisporites australiensis, Cookson (1953); Potonie (1956); 4a, 4b, 5 and 6 = Cicatricosisporites subrotundus, Brenner (1963). 


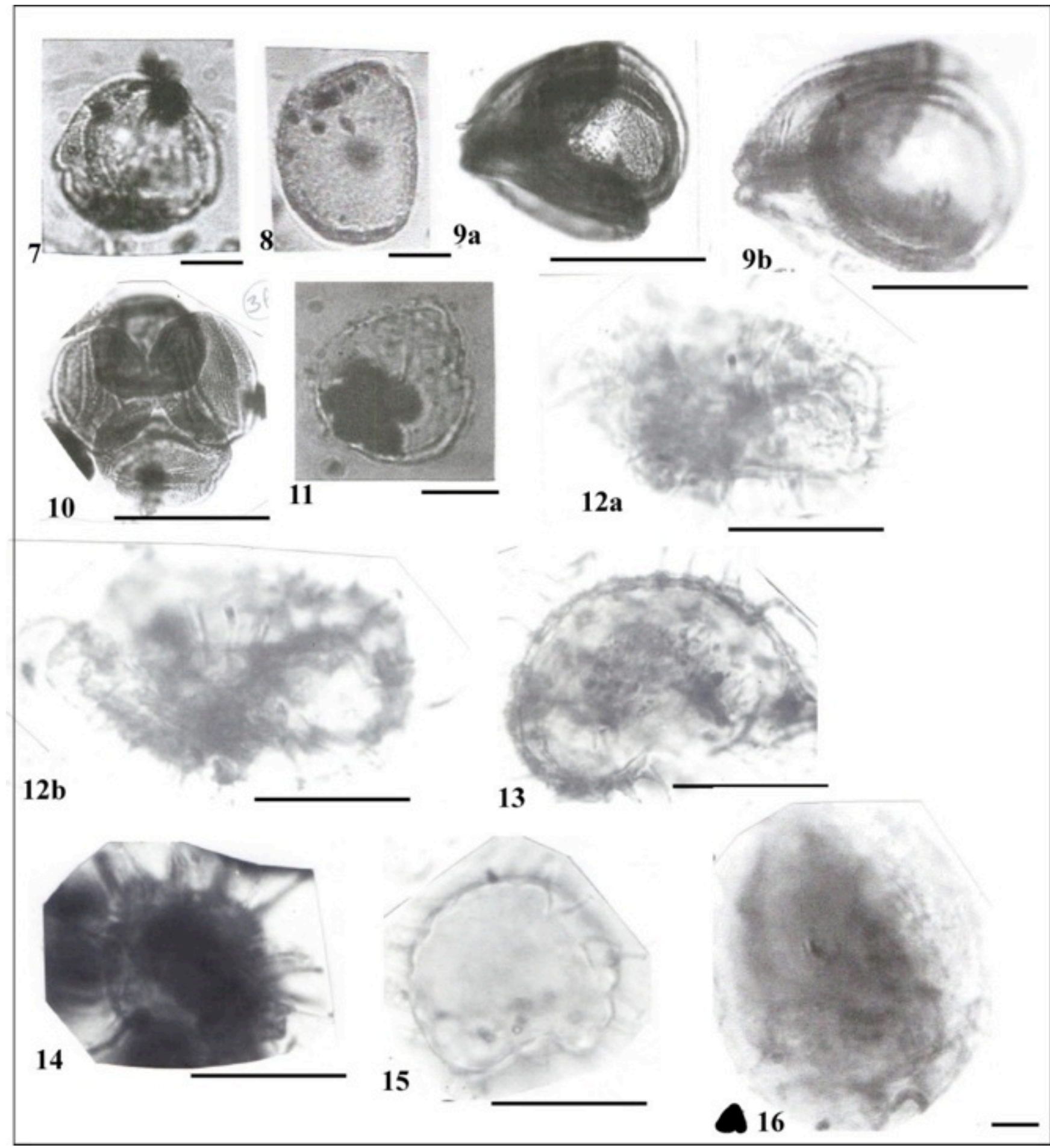

Scale bar $=\mathbf{3 0} \boldsymbol{\mu}$

Fig. (8). Zone B1 continues Legend 7 and $\mathbf{8}=$ Classopollis brasiliensis, Herngreen (1975); 9a and 9b = Classopollis brasiliensis, Herngreen (1975) (fit together double V tetrad); $10=$ Classopollis brasiliensis, Herngreen (1975) (spread out double V tetrad); $11=$ Classopollis sp. cf. C. jardinei; 12a, 12b, 13 and $\mathbf{1 4}=$ Exochosphaeridium bifidum, (Clarke \& Verdier) Clarke et al. (1968); $15=$ Polysphaeridium aff. $P$. pastielsi, Dav. and Wil. (1966); 16 = Inaperturopollenites giganteus, Goczan (1964).

Cretaceous to Senonian dinocysts such as Cribroperidinium sp. cf. C. Tensiftense, Subtilisphaera pirnaensis, Spiniferites ramosus, Spiniferites ramosus subsp. ramosus, Triblastula borussica, places it between the late Cenomanian to early Turonian, given its stratigraphic position and its known paleontological content.

\subsubsection{Zone C}

As already mentioned above, calcareous and argillaceous facies are marked by the persistence of Palaeohystrichosphora infusorioides and the presence of 


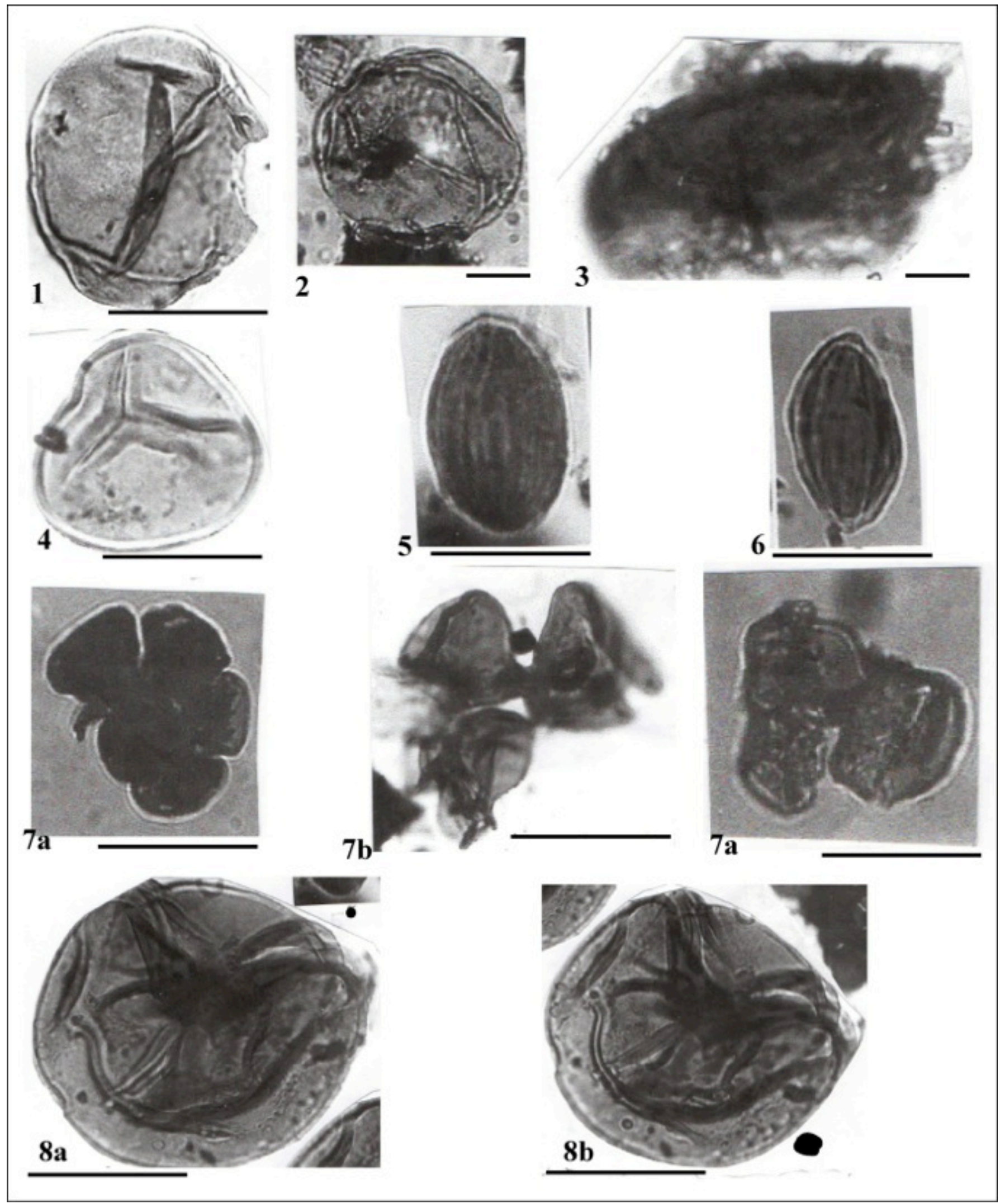

Scale bar $=\mathbf{3 0} \boldsymbol{\mu}$

Fig. (9). Zone B2 legend: 1 = Araucariacites australis, Cookson (1947); 2 = Araucariacites australis, Cookson (1947); 3 = Acanthotriletes sp. aff. A. rarispinosus; $4=$ Cyathidites minor, COUPER (1953); 5 and $\mathbf{6}=$ Ephedripites sp., Herngreen (1973); $7=$ chitinous Microforaminifera; $\mathbf{7 a}=$ Rhodonascia $\mathrm{sp}$. cf. R. bontei, $\mathbf{7 b}$ and $\mathbf{7} \mathbf{c}=$ Trochiliascia sp. cf. T. cuvillieri; $\mathbf{8 a}$ and $\mathbf{8 b}=$ Triporoletes $\mathrm{sp}$. cf. Tympanoideus, Srivastava (1972). 


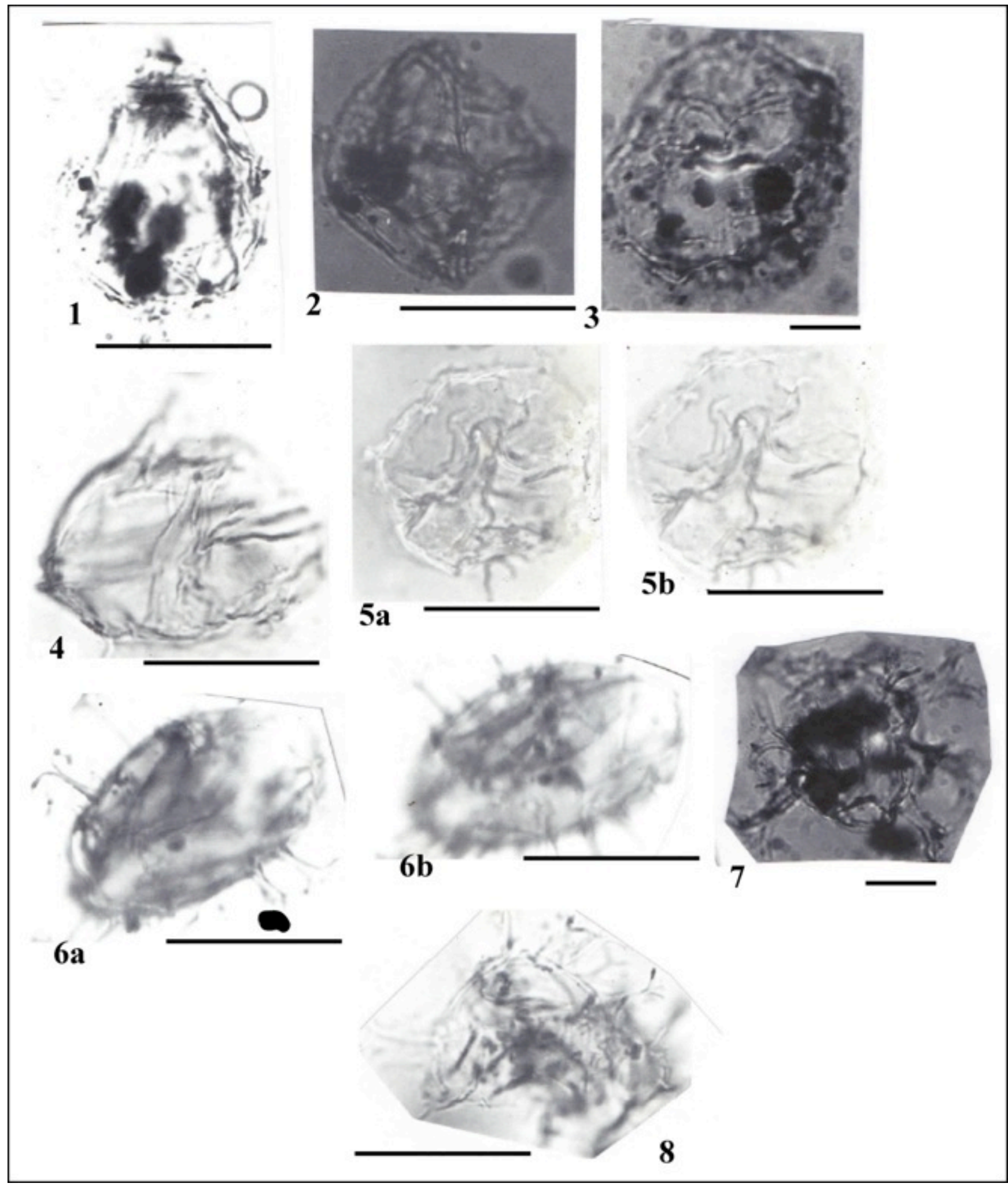

Scale bar $=\mathbf{3 0} \boldsymbol{\mu}$

Fig. (10). Zone B3 Legend: $\mathbf{1}=$ Cribroperidinium sp. cf. C. Tensiftense, 2, 4, 5a and $\mathbf{5 b}=$ Subtilisphaera (Deflandrea) pirnaensis (Alberti) Jain \& Millepied (1973); 3 = Subtilisphaera (Deflandrea) pirnaensis (Alberti) Jain \& Millepied (1973); 6a and $6 \mathbf{b}=$ Spiniferites ramosus (Ehrenberg) Loeblich \& Loeblich (1966) var. multibrevis Davey \& Williams (1966); 7 = Spiniferites ramosus subsp. Ramosus (Ehrenberg) Loeblich \& Loeblich (1966); 8 = Triblastula borussica (Eisenack, 1954); Morgenroth (1966).

Monocolpites sp., Proteacidites sp. and Erdtmanipollis cf. E. pachysandroides which make it possible to fix their ages from late Turonian to early Senonian, constituting zone C (Fig. 11). 


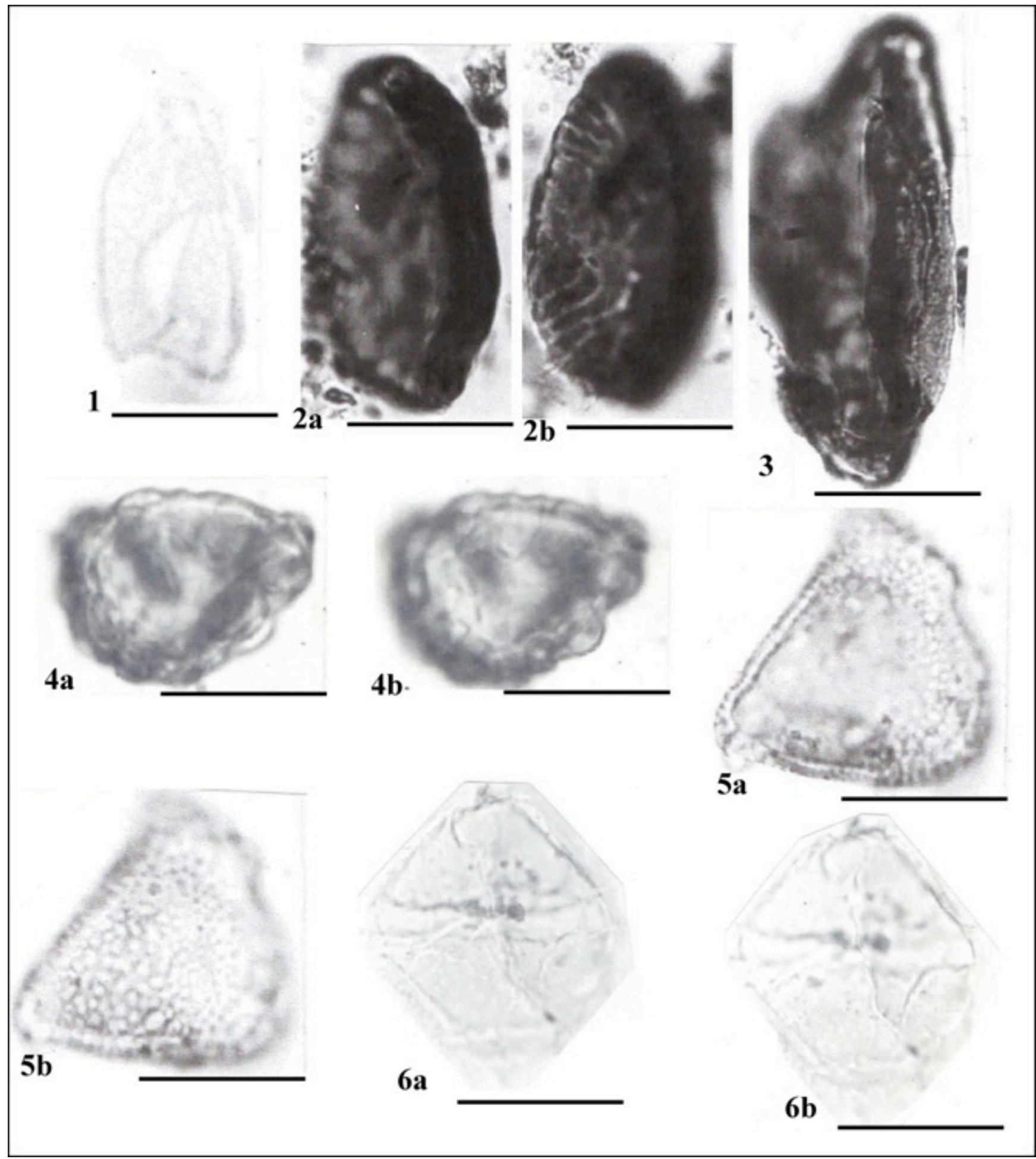

Scale bar $=\mathbf{3 0} \boldsymbol{\mu}$

Fig. (11). Zone C legend: 1 = Monocolpites sp. aff. Gemmazonocolpites sp. in Jan du chëne (1977); 2a, 2b and 3 = Monocolpites sp.; 4a and $\mathbf{4 b}=$ Erdtmanipollis cf. E. pachysandroides, Krutzsch (1962); 5a and 5b = Proteacidites sp.; 6a and $\mathbf{6 b}=$ Palaeohystrichophora infusorioides.

It should be noted that the quantitative and qualitative analysis of palynomorphs confirmed the continental nature of the deposits. However, the presence of dinophyceae and chitinous microforaminifer fossils (Trochiliascia sp. cf. $T$. cuvillier) confirms a brief marine incursion at the base of the Douala basin during the mid-Cretaceous [10].

\section{DISCUSSION}

\subsection{Sequence Analysis}

Stratigraphic description of the studied area has highlighted a succession of facies ranging from polygenic 
conglomerates at the bottom, with fine laminations of black clay, clayey sands and silty clays at the top. These facies display a turbiditic characteristic of the Bouma [40] type.

\subsubsection{Basal Sequence}

It is turbiditic and composed of two depositional units, one at the base and another at the top. Their age probably extends from middle to upper Cenomanian.

Depositional unit 1 forms the base of this sequence. It consists primarily of composite gravity sediment deposits. These deposits are conglomerate mixtures or polygenic breccias between which there are levels of intercalated clayey sands.

Depositional unit 2 forms the upper part of this sequence. It shows signs of intermittent infiltration of water laden with more fine turbid detrital particles. It is marked by a serie of small sequences consisting of a few fining-upward levels, which are associated with fine parallel laminations of black clay, clayey sands and silty clays, which alternate regularly. These short sequences are similar to elementary regressive sequences defined by Cojan and Renard [41]. This type of sequence of composite gravity sediment deposits at the bottom, a layer of coarse grains forming the grain flow, and at the top finer laguno-lacustrine facies is analogous to fluxoturbidites [42]. According to Mutti and Ricci Lucchi [43] it is rather a "positive sequential unit" of the finingupward category. This conglomerate corresponds to channel filling deposits [30]. They are interpreted as relating to a dynamic fluvio-deltaic deposition that belong to the upper fan deposits type. Cretaceous sediments of the Douala basin are gravitational deposits that form turbid accumulations similar to that of terrigenous detrital river mouth formations of the river-delta type [10].

To summarize, this turbiditic basal sequence represents a sand with the conglomerates at the base, parallel clay laminations in fine-grained facies and thin calcareous clay and limestone layers at the top such as association characterizes sedimentation process that could be described as fluxoturbiditic.

\subsubsection{Top Sequence}

The Turonian sequence begins with a level of quartz pebbles, which overlie depositional unit 2 and forms the base of the coarse detrital layer of fining upward elements overlain by fine sands. It marks the beginning of a small marine incursion. This conglomeratic deposit is followed by an essentially pelitic level [10], a level that consists of an alternation of thin calcareous and grey to black argillaceous layers. This conglomerate forms depositional unit 3. It reflects the continuing presence of a shallow and relatively confined sea. This trend continues throughout the rest of the Turonian with predominantly black clay that is rich in organic matter.

All these regressive elementary sequences make a transgressive megasequence [41].

\subsection{Paleogeographic Reconstitution}

Sequence analysis of the studied facies shows that they consist of small positive sequences formed in short regressive periods and whose rhythmic succession forms a transgressive megasequence. This is confirmed by a general fining-upward trend and finally replaced by small scale of marl and limestone facies. Moreover the gradual evolution of sediment from the base to the top of the studied series, shows how difficult it was for the marine incursion to remain at the southern part of the Douala basin, difficulty that was due to the blockage of the continental tear in the area of present day of the Gulf of Guinea (Douala, Limbe, Malabo). This makes it possible to conclude that the sediments were deposited in this part of the basin during the transgressive megaphase which continued after the rift filling. During this period, the evolution of depositional environments could only be determined from the abundant plant material found in each of these environments that show different characteristics from the early Cenomanian to Turonian. This evolution is specified as follow:

\subsubsection{From Early Cenomanian to Middle Cenomanian}

The opening of the South Atlantic reached the eastern edge of the Douala basin. The depositional environment is a narrow rift of a few hundred metres wide and fairly steep walls (Fig. 12A). The sediments are mainly terrigenous and coarse, with angular elements, indicating severe aridity. However, quantitative analysis of the palynomorphs shows a clear predominance of pteridophytes trilete (filicophytes) on the spermaphytes. This is probably the result of humidification in the region due to proximity of marine waters in the South (between Kribi and Campo).

\subsubsection{From Middle Cenomanian to Late Cenomanian}

The E-W distension movement of both the South American and African plates expanded the tectonic rift that allowed sea water from the south to infiltrate into the area (Fig. 12B). But filling of the area with water was made difficult by both large detrital clutter that filled the channel and northern blockage of the continental tear. However the series of synthetic and antithetic normal faults that generated a 'piano keys' structure (alternating horsts and grabens) isolated small depression that received water and formed small lakes of very varied sizes [8]. The milieu became lagoonal-lacustrine with the lagoon filled mainly with sea water. This is confirmed by the presence of dinoflagellate cysts which represent $21.42 \%$ of the all palynomorphs found in this milieu. However, pteridophytes remain dominant and ephedraceae began to sprout because of the influence of the proximity of a watered and green continent. This was the beginning of a marine transgression [10]. In the late Cenomanian, less coarse terrigenous sedimentation continued and filled all the small lakes. This caused the decline of marine waters to the south, leaving a marshy environment characterized by very hydromorphic sandy clay deposits. This environment is marked by many episodes of thin clay deposits rich in organic matter and silt. The stabilization of the sea a little further south, led to the complete absence of dinophyceae and continued dominance of pteridophytes.

\subsubsection{From Late Cenomanian to Turonian}

Widening of the rift that started in the Cenomanian continued with resumption of the opposite lateral translation 

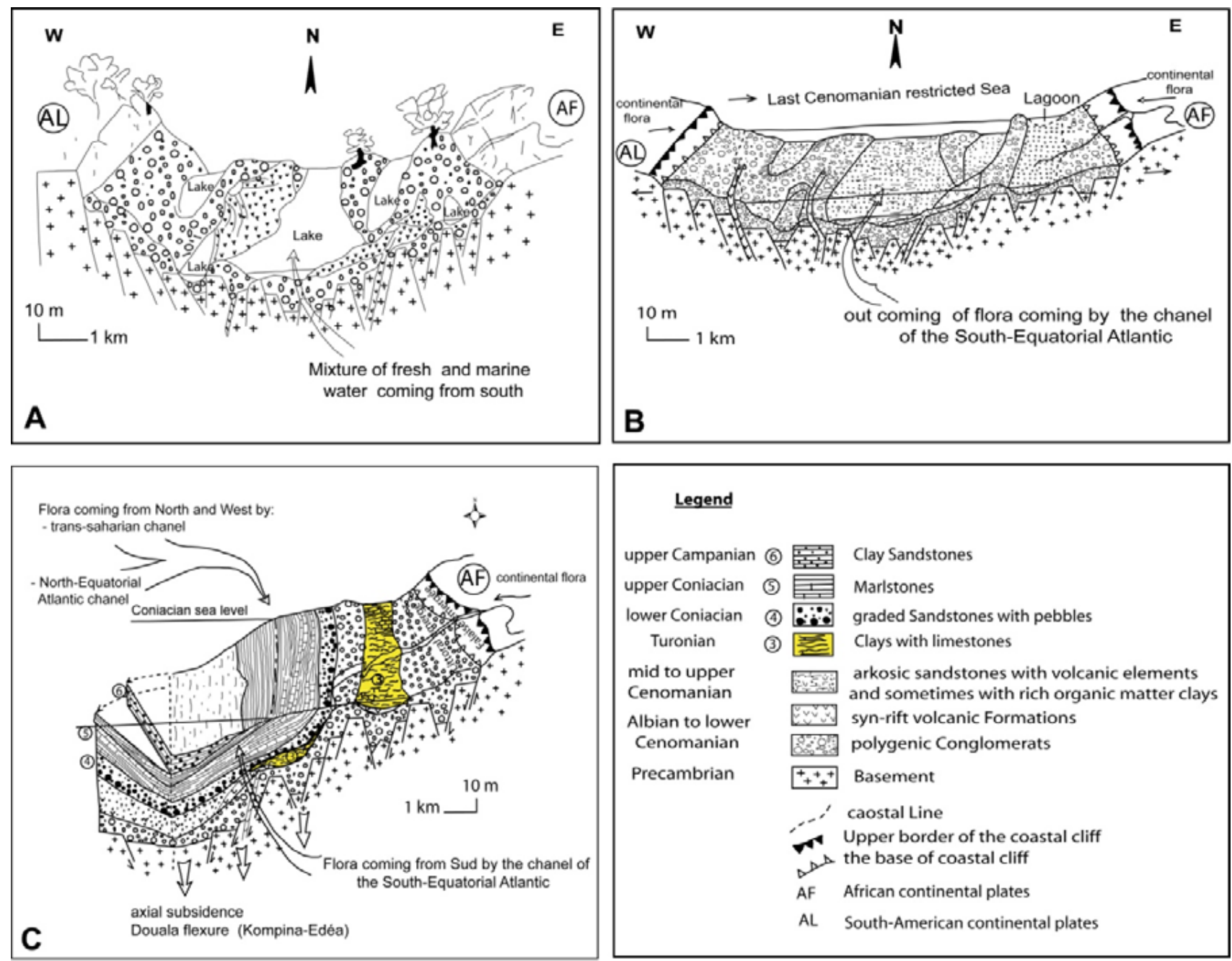

\begin{tabular}{|lll}
\hline Legend & \\
upper Campanian (6) &
\end{tabular}

Fig. (12). Palaeogeographic evolution of the eastern edge of Douala basin from early Cenomanian to Turonian: A) early Cenomanian to middle Cenomanian; B) middle Cenomanian to late Cenomanian; C) late Cenomanian to Turonian.

movement of the South American and African plates to compensate for the blocking of the rotational movement of the marine trans-continental opening that started in the late Albian [44]. Significant subsidence of the faulted basement occurred. The sudden collapse of the entire block caused a rise in the marine transgression toward the north, creating a confined and shallow sea (Fig. 12C). This is justified by the abundance of dinophyceae, the presence for the first time since the Cenomanian, of chitinous microforaminifers [10].

\section{CONCLUSION}

Sedimentological and palynostratigraphic analyses carried out on deposits cropping out at the eastern edge of the Douala basin helped to identify terrigenous detrital deposits at the base and marine deposits at the top of the studied series. The depositional process of these first deposits at the bottom of the basin were regulated by a hydrodynamic regime dominated by gravity flow, followed by a gradually decreasing energy stream and lastly by a shallow sea.
Sequence analysis of these deposits helped to identify positive short sequences whose rhythmic succession formed a transgressive megasequence. These deposits were dated early Cenomanian at the base and Turonian at the top. They were deposited in an environment which is successively a confined rift, lagoonal-lacustrine and paludal, and finally shallow marine. The nature of these depositional environments is related to the South Atlantic opening tectonics. The climate very likely remained warm and increasingly became humid. The tectono-sedimentary evolution resulted in the opening a rift valley in the early to middle Cenomanian, followed by a more or less extensive basin subsequent to the $\mathrm{E}-\mathrm{W}$ distensive movement between the South American and African plates during the middle to late Cenomanian lastly, the subsidence and rift sequences led to the installation of a small, shallow and confined sea during the Turonian.

\section{CONFLICT OF INTEREST}

The authors declare that they have no conflict of interest. 


\section{ACKNOWLEDGEMENTS}

The authors, particularly Dr. Njike Ngaha wishes to thank the German organisation DAAD for the grant offered in 1991 that permitted to realize palynological analyses. Our gratitude is also expressed to the former laboratory of palynology of the University of Göttingen in Germany where the main part of these studies were undertaken. Many thanks to the former "South-East Mining Project" in Cameroon which conducted some useful drilling with good and fresh core samples offered for the present purpose. Our gratitude is expressed finally to the anonymous reviewers for their useful suggestions for improving the readiblity of this manuscript.

\section{REFERENCES}

[1] Ngaha PRN, Belinga SME. The diachronism of the basal sandstone, paleoenvironment and the role of the opening of the South Atlantic. Annals of the Faculty of Sciences, Earth Science, Series IV, 1987; 1 (3-4): 103-19.

[2] Reyre D. Remark on the evolution of African Atlantic coastal sedimentary basins. Bull Soc Géol Fr 1984; 36: 1041-59.

[3] Rabinowitz PD, Labrecque J. The Mesozoic South Atlantic Ocean and evolution of its continental margins. J Geophys Res 1979; 84 (11): 5973-6002.

[4] Meyers JB, Rosendahl BR, Groschel-Becker H, Austin Jr JA, Rona PA. Deep penetrating MCS imaging of the rift-to-drift transition, offshore Douala and North Gabon basins, West Africa. Mar Petrol Geol 1996; 13 (7): 791-835.

[5] Belmonte YC. Stratigraphy of the Cameroon sedimentary basin. In: Proceedings of the $2^{\text {nd }}$ West African Micro-paleontological Colloquium, Ibadan, 18 June-1 July 1966; pp. 7-24.

[6] Reyre D. Geological history of the Douala basin. In: Reyre D, Eds. Symposium on the sedimentary basins of the African coast. African Association of Geological Services, IUGS: Paris 1966; pp. 143-61.

[7] Dumort JC. Explanatory notice of the sheet Douala West. Geological Recognition Map at scale 1/500,000. Department of Mines and Geology: Cameroon 1968; p. 69.

[8] Ngaha PRN. Contribution to the geological, stratigraphic and structural Study of the Atlantic border of Cameroon sedimentary basin. $3^{\text {rd }}$ cycle Thesis: University of Yaounde 1984; p. 131.

[9] Ngaha PRN, Belinga SME. Evidence of two distinct structural domains in the southwest of Cameroon using the photointerpretation methods. Annals of the Faculty of Science, Earth Science, Series IV, 1987; 1(3-4): 69-81

[10] Ngaha PRN. Palynostratigraphy and reconstruction of the Cretaceous paleoenvironments of the east of Douala sedimentary basin (Cameroon). Ph.D Thesis: University of Yaounde I 2005; p. 259.

[11] Nguene FR, Tamfu SF, Loule JP, Ngassa C. Palaeoenvironments the Douala and Kribi/Campo sub-basins, in Cameroon, West Africa. In: Curnelle R, Ed. African Geology, $1^{\text {st }}$ Colloquium on Stratigraphy and Paleogeography of West African Sedimentary Basins, $2^{\text {nd }}$ Colloquium of African Micropaleontology. Libreville 1991, Boussens: Elf Aquitaine 1992; pp. 129-39.

[12] Logar JF. Well evaluation conference. West Africa. Schlumberger Document 1983; pp. 1-69.

[13] Boltenhagen E, Salard-Cheboldaeff M. The continental and marine domain: Gabon and Cameroon Coastlines sedimentary basin. Bull Sci Géol Str 1985; 38 (1): 35-44.

[14] Mascle J. The Gulf of Guinea (South Atlantic): a set of evolution in shear of Atlantic margins. Mem Soc Géol Fr 1976; 128: 1-104.

[15] Guieu G, Roussel J. Une interprétation des bassins côtiers ouestafricains à partir de l'histoire des dépôts salifères dans le cadre de l'ouverture de 1'Atlantique. Bull Soc Géol Fr 1984; 6 (7): t. XXVI: pp. 1149-64.

[16] Séguret M. Evolution de la marge passive type Afrique de l'Ouest. Mem. Centre de rech. Explor.-Prod. Elf Aquitaine, 1988; 7: pp. 631.

[17] Benkhelil J, Giresse P, Poumot C, Ngueutchoua G. Lithostratigraphic, geophysical and morpho-tectonic studies of the south Cameroon shelf. Mar Petrol Geol 2002; 19: 499-517.
[18] Pauken RJ. Sanaga Sud field, offshore Cameroon, West Africa. In: Halbouty MT, Eds. Giant oil and gas fields of the decade 19781988. American Association of Petroleum Geologists Memoir., 1992; vol. 54: pp. 217-30.

[19] Miall AD. Architectural-element analysis: a new method of facies analysis applied to fluvial deposits. Earth Sci Rev 1985; 22: 261308.

[20] Miall AD. The geology of fluvial deposits: Sedimentary facies, basin analysis, and petroleum geology. Springer-Verlag, NewYork, 1996: p. 582.

[21] Walker RG, Cant DJ. Facies model 3: Sandy braided systems. Geoscience of Canada, Reprint Services 1984; 1: p. 23-31.

[22] Postma G. Depositional architecture and facies of river and fan deltas: a synthesis. In: Colella A, Prior DB, Eds. Coarse-grained deltas. Special Publications of International Association of Sedimentologist 1990; vol 10: pp. 13-28.

[23] Nilsen TH. Alluvial fan deposits. In: Sholle PA, Spearing D, Eds. Sandstone depositional environments. American Association of Petroleum Geologists Memoir. vol 31: pp. 49-86.

[24] Fisher RV. Features of coarse-grained, high concentration fluids and their deposits. J Sediment Petrol 1971; 41: 916-27.

[25] Nemec W, Steel RJ. Alluvial and coastal conglomerates: their significant features and some comments on gravelly mass-flow deposits. In: Koster EH, Steel RJ, Eds. Sedimentology of gravels and conglomerates. Memoir of Canadian Society of Petroleum Geology, Calgary 1984; vol 10: pp. 1-31.

[26] Miall AD. Alluvial sedimentary basins. Tectonic setting and basin architecture. In: Miall, AD, Ed. Sedimentation and tectonics in alluvial basins. Geological Association of Canada: Special Publication 1981; 23: pp. 1-33.

[27] Ghibaudo G. Subaqueous sediment gravity flow deposits: practical criteria for their description and classification. Sedimentology 1992; 39: 423-54.

[28] Allen JRL. Physical processes of sedimentation. In: Walker RG, Eds. Facies models. New York: American Elsevier 1970: p. 248.

[29] Collinson JD. Vertical sequence and sand body shape in alluvial sequences. In: Miall AD, Ed. Fluvial Sedimentology. Canadian Society of Petroleum Geologists Memoir 1978; 5: pp. 577-86.

[30] Chamley H. Base de Sédimentologie. $1^{\text {st }}$ ed. Dunod, Paris. ISBN10: 2100048848 1999; pp. 178.

[31] Rust BR. Depositional model for braided alluvium. Can Soc Petrol Geol 1978; 5: 605-25.

[32] Cant DJ. Development of a facies model for sandy braided river sedimentation. Comparison of the South Saskatchewan River and the Battery Point Formation. In: Miall AD, Ed. Fluvial sedimentology. Can Soc Petrol Geol Memoi 1978; 5: 627-41.

[33] Walker RG, Cant DJ. Facies model 3: Sandy braided systems. Geo Sci Canada Rep Ser 1978; 1: 23-31.

[34] Collinson JD. Alluvial sediments. In: Reading HG, Eds. Sedimentary environment and facies. Blackwell Scientific: Oxford 1986; pp. 20-62.

[35] Mutti E, Tinterri R, Di Biase D, et al. Delta-front associations of ancient flood-dominated fluvio-deltaic systems. Revista Sociedad Geologica Espana 2000; 13 (2): 165-90.

[36] Gugliotta C, Agate M, Sulli A. Sedimentology and sequence stratigraphy of wedge-top clastic successions: Insights and open questions from the upper Tortonian Terravecchia Formation of the Scillato basin (central-northern Sicily, Italy). Mar Petrol Geol 2013. doi: 10.1016/j.marpetgeo.2013.02.004.

[37] Doukaga AM. Palynoplanctonic study in the early and middle Cretaceous of Gabon sedimentary basin. Specialty thesis. Univ Sci Techn Lille 1980; 823 (2): 174.

[38] Andreeff J. Geological research mission in Cameroon - December 1946 - July 1949. General Report: Research Office of Petroleum; 1950.

[39] Laplaine L. Report of the geological section for the 1963 campaign. Geological study and exploration of Buea-Douala-WEST sheet. From Dumort. Publ Dir Mines Geol Cameroon 1963.

[40] Bouma AH. Sedimentology of some flysch deposits. A graphic approach to facies interpretation. Amsterdam: Elsevier 1962.

[41] Cojan I, Renard M. Sédimentologie. Un bon Ouvrage Récent (en Français) de Sédimentologie Intégrant les Derniers Développements (Analyse Séquentielle, Diagenèse,). Pas Beaucoup de Photographies, Mais de Bons Schéma. $1^{\text {st }}$ ed. Dunod: Paris 2006; p. 444. ISBN-10: 2100496239. 
[42] Slaczka A, Thompson III S. A revision of the fluxoturbidite concept based on type examples in the Polish Carpathian flysch.

Annales Societatis Geologorum Polaniae/Rocznik Polskiegs Towarzystwa Geologicznego, Karkow 1980; 51: 3-44.
[43] Mutti E, Lucchi RF. The meaning of some sequential units in turbidites series, Bull Soc Géol Fr 1974; 6 (7): 577-82.

[44] Förster R. Evidence of an open seaway between northern and southern proto-Atlantic in Albian times. Nature 1978; 272 (9): 158-

9.

(C) Ricard et al.; Licensee Bentham Open.

This is an open access article licensed under the terms of the Creative Commons Attribution Non-Commercial License (http://creativecommons.org/licenses/bync/3.0/) which permits unrestricted, non-commercial use, distribution and reproduction in any medium, provided the work is properly cited. 